2021, Volume 16, ATEE 2020 - Winter Conference. Teacher Education for Promoting WellBeing in School. Suceava, 2020, pages: 385-396|

https://doi.org/10.18662/lumproc/atee2020/26

\section{Paradigms in Modern Higher Education Development}

\section{Halyna RADCHUK ${ }^{1}$ \\ Zoryana ADAMSKA ${ }^{2}$ \\ Mariia OLIINYK ${ }^{3}$ \\ Solomiia CHOPYK ${ }^{4}$}

${ }^{1}$ Doctor of Psychology, professor, head of Developmental Psychology and Counseling Department, Ternopil Volodymyr Hnatiuk National Pedagogical University, Ternopil, Ukraine,galyna012345@gmail.com

${ }^{2} \mathrm{PhD}$ in Psychology, Associate Professor of Developmental Psychology and Counseling Department, Ternopil Volodymyr Hnatiuk National Pedagogical University, Ternopil, Ukraine, zoryanada@ukr.net

${ }^{3}$ Doctor of Pedagogy, professor, head of Pedagogy and Psychology of Preschool Education Department, Yuriy Fedkovych Chernivtsi National University, Chernivtsi, Ukraine, oliynykm69@ukr.net

${ }^{4} \mathrm{PhD}$ in Psychology, Associate Professor of Developmental Psychology and Counseling Department, Ternopil Volodymyr Hnatiuk National Pedagogical University, Ternopil, Ukraine, solomiabodnar@ukr.net
Abstract: The theoretical and methodological analysis of modern educational paradigms is made in the article and axiological vectors of bigher education development are distinguished on this basis. Four basic educational paradigms have been identified: cognitive informational (traditional, cognitive), personal (bumanistic), competence and cultural (bumanitarian). It has been found that, unlike instrument-oriented learning, which provides the translation, reproduction and assimilation of knowledge, skills, technologies (cognitive informational and competence paradigms) and therefore is secondary to the processes of personality development, education should firstly be focused on becoming bolistic personality, ensure his organic and unique (personal and cultural paradigms). It has been substantiated that at the theoretical level there is a sharp narrowing of the semantic field of scientific and pedagogical reflection: attention is paid to the production of the amount of knowledge, given social behavior, technologies of activity of the future specialist. Therefore, education in its bumanitarian sense suffers first of all and the quality of education is often reduced to the level of acquisition of special knowledge and mastery of professional skills. It has been shown that higher education institutions are more and more inclined to a pragmatic education, training professionals, and functionaries. In this case, information overload blocks the affective-emotional sphere of the individual, prevents adequate, holistic perception of reality, actualization of creative potential. It is determined that the reform of modern education should be based on the idea of the integrity, which actualizes the problem of careful reflexive and methodological support of the modern higher education system and the development of specific bumanitarian educational technologies.

Keywords: education; educational paradigm; cognitive informational paradigm; personal paradigm; competence paradigm; cultural paradigm

How to cite: Radchuk, H., Adamska, Z., Oliinyk, M., \& Chopyk, S. (2021). Paradigms in Modern Higher Education Development. In O. Clipa (vol. ed.), Lumen Proceedings: Vol. 16. ATEE 2020 - Winter Conference. Teacher Education for Promoting Well-Being in School. Suceava, 2020 (pp. 385-396). Iasi, Romania: LUMEN Publishing House.

https://doi.org/10.18662/lumproc/atee2020/26 


\section{Introduction}

A leading feature of the current stage of higher education development is the search for new approaches to enhance its compliance with the requirements of the twenty-first century. The importance of research in this sector is conditioned by the high social importance and perspective of national higher education development in the context of Ukraine's accession to the European educational space.

That is why the problem of clarifying and concretizing the educational paradigm of higher education, identifying the main characteristics of the modern educational process through consideration of education in a broad socio-cultural context is quite acute today.

The development of education is based on broad philosophical ideas and is filled with philosophical content. The philosophy produces the creation of new educational concepts, setting the direction of scientific search, acting as a methodological basis for the development of new educational theories.

The formation of a new conception of education in the early 21 st century is associated with the emergence of a new philosophical picture of the world based on recognition of its openness and self-organization. The philosophy of education examines how the personal development on a man in the cultural environment occurs and how the education system can (and should) contribute to this process.

Therefore, the aim of the study is to analyze the existing educational paradigms in a philosophical context, which will help us to identify the main axiological vectors of higher education development.

Research methodology. Interdisciplinary analysis and thorough theoretical and methodological reflection of modern scientific discourse of paradigms in modern education the development, its essential values, as well as its systematic consideration in the context of modern paradigmatic changes, on the basis of review of psychological and psychological literature has been done.

\section{Analysis of recent research and publications}

Hereinafter the educational paradigm will be interpreted as a set of established meaningful characteristics that determine the essential features of educational activity models and interaction of the educational process participants.

Within the framework of the philosophy of education, the problem of finding a new educational paradigm is particularly relevant. As the outset 
it worth noting that in philosophical literature it has been criticized the traditional understanding of educational process as a kind of "social inheritance", process of ascending on the "civilizational ladder", focused on the "production" of people with predetermined qualities. Psychologists and educators are also unanimous in the fact that the educational process is often described as a process of technical production according to officially recognized and pre-known criteria and models.

Today, in philosophy it is clearly outlined the orientation on overcoming the Scientian position to stop the negative processes in education. The philosophers are concerned about the rapid devaluation of the apex values. Thus, analyzing the value orientations of modern education, philosophers emphasize on the ability to awake the "human" in man (his spirituality, desire for self-knowledge, self-development) as the most important criterion for its effectiveness (Gusinsky \& Turchaninova, 2000; Kagan, 2007).

Studying the educational paradigms, E. Gusinskyj and Y. Turchaninova came to the conclusion that all diversity of values of the education can be divided into two main groups: the (1) values of preserving the existing order of things and (2) the value of its transformation (Gusinsky \& Turchaninova, 2000).

\section{The results of the research}

Interdisciplinary analysis and deep theoretical and methodological reflection made it possible to state the fact of narrowing the understanding of the concept of "education", which is a serious obstacle to the implementation of the essential values of education. This led to a systematic examination of higher education in the context of contemporary paradigm changes and a profound immersion in the analysis of philosophical, sociological, cultural, psychological and pedagogical sources.

Thus, in general, it can be stated that the discussion, which has been developed around the values of modern education reflects the clash of four educational paradigms: cognitive informational, personal, cultural and competence. Each of these paradigms adequately reproduces only part of reality and fixes its attention on what can be considered the result of education.

The cognitive informational (cognitive, traditional) paradigm reflects the necessity of transferring to personality the maximum amount of all knowledge and skills accumulated by mankind; interprets the orientation of the educational process in a certain way, orienting teachers to subject programs, fixed results, etc. Therefore the desires, personality needs, as a 
rule, are not taken into account. This paradigm is based on a powerful tradition dating back to Aristotle. Psychologists have already evaluated the cognitive informational paradigm of education as deodorizing for the individual.

The traditional model of education is generally accepted as too static, monologue, oriented towards the disciplinary distinction of knowledge in the form of relatively autonomous, closed systems of information retention, which should be "embedded" in the heads of students. This model is largely closed and virtually incapable to development, and therefore becomes increasingly inadequate to the modern realities of the global change process. The consequence of this is not only the fragmentation of reality, but also its deformation, which in the conditions of post-industrial/information society does not allow people to respond adequately to the ecological crisis, leads to the devaluation of moral norms and values.

The personal paradigm is concentrated on the emotional and social development of the person. The essence of a personally oriented paradigm of education lies in the considering of a person as a complex self-organized system, in recognizing the uniqueness, self-worth of each man and the vector of his development; in shifting of education goals from the informatization of personality to creating conditions for his selfdetermination and self-development; in developing the subjective position of the teacher in the educational process, which should provide the personal meaning to the activities of learners, create space for the manifestation and development of their individuality, give freedom of choice. Personally oriented technologies are of particular importance, because they emphasize the value of the individual; produce a positive attitude towards people and oneself; indicate the need for partnership in relationships; imply the development of the spiritual qualities of the individual, respect and care for each person, empathy, ability to co-exist, naturalness and openness of relationships as a significant indicator of personal development (Rogers \& Freberg, 2002).

Thus, the humanization of education, on the one hand, is a condition for the harmonious development of the individual, the enrichment of his creative potential, the growth of essential forces and abilities, and on the other hand - a process aimed at the development of the individual as a subject of creative activity. At the same time, the humanization of education is an important characteristic of the lifestyle of educators and students, which involves establishing genuine human relationships between them in the learning process.

At the same time scientists look for and develop the cultural models of education (Asmolov, 1996; Bondarevskaya et al., 2005). The main 
function of these models is the humanitarian one, which is to preserve and restore the ecology of man, his physical and spiritual health, the meaning of life, personal freedom and morality. Due to the cultural paradigm the teacher has to be focused on the main task - a child personality development. This paradigm dictates that the achievement of completeness and integrity of the worldview goes far beyond pragmatic cognitive-pedagogy. Its main task is in the education of a spiritual person.

E. Bondarevskaya notes: "Education must be filled with cultural meanings. The cultural meanings of education are supposed to be human" (Bondarevskaya et al., 2005, p. 116). Thus, the issues of meaning-making, holistic understanding, and personal knowledge she puts on the first position in education. Due to this, education is intended to create a space for cultural development, a field for interaction of ideal (cultural) and real sensory forms. To help a person to make a dialogue with other cultures, people, to comprehend and feel their values, to listen to own inner voice, to realize oneself, the meaning of one's own existence and to define one's own place in the culture, and, therefore, in life are the main and the most essential tasks of modern education.

The competence paradigm grows from cognitive informational one. However, unlike the last one, it is aware of the impossibility and meaninglessness of the infinite dissemination of information passed on to future generations. Due to it the expected result of the educational process is not a system of knowledge and skills, but a set of key, declared competencies without which the activity of the modern person in the intellectual, social, political, communicational, informational and other spheres is impossible. The competence paradigm is aimed at enhancing the practical orientation of education; training well skilled and mobile person, who owns not the set of facts, but the methods and technologies of obtaining them.

\subsection{Comparative analysis of value vectors of modern educational paradigms}

The education must reproduce a coherent entity of culture and activity, a person in its existential and ontological fullness. Unlike instrument-oriented learning, which provides the translation, reproduction and assimilation of knowledge, skills, technologies (cognitive informational and competence paradigms) and therefore is secondary to the processes of personality development, education must firstly be focused on the development of a coherent man, ensure his identity and uniqueness (personal and cultural paradigm). If higher education excludes the spiritual and moral essence of a person and is focused only on transferring of the maximum amount of knowledge and assimilating of technologies, it does 
not ensure the professional success of the specialist-personality and inevitably leads to a socio-cultural and personal identity crisis.

In our view, in the system of cognitive informational and competence paradigms, a person is perceived not in his/her identity and integrity, but through the prism of functionally defined parameters success, discipline, behavior, etc. Therefore, the cognitive informational component of education must be instrumental in its core value - cultural, value-meaning development of the individual.

M. Kagan, analyzing the crisis state of modern education, notes that it primarily occurs because of neglecting of holistic and systemic structure of the human psyche for the existence and functioning of which in the process of education it is necessary to ensure the implementation of five major activities:

1) "cognitive, the aim of which is to obtain the information about the object by the subject; the highest form of it is science in all its modifications, from mathematics to psychology;

2) value-oriented, the aim of which is the awareness of the object value for the subject; the highest form of it is ideology in all its various modifications, from religious to aesthetic;

3) transformative, the aim of which is to change the object by the subject; the highest form of it is material, practical and spiritual-ideal activity for the creation of a new cultural object from natural, social, human given material...;

4) communication as an interpersonal interaction, the aim of which is to achieve the unity of subject and object while maintaining the subjective uniqueness of each (it can be an interpersonal, intergroup, when a social group, from a creative team to a nation, acts as a "aggregate entity", and intrapersonal dialogue, when the personality is polysubjective and his consciousness becomes the arena of internal dialogue;

5) art development of the world, in which all four mentioned above homogeneous activities are syncretically merged in mythological consciousness and in the perception of the child, and later syncretically mutually identified in art" (Kagan, 2007, p. 228).

Current education does not ensure the functioning of all five activities, focusing on the development of cognitive and analytical abilities of the individual. First of all, this is ensured by the implementation of cognitive informational and competence paradigms. Spiritual life is reduced to the ability to learn and develop useful rational functions.

According to E. Fromm, any educational paradigm can be correlated with one of the modes of human existence - "to be" or "to have". Modus "to have" involves the change of external to human circumstances and 
alienated activity aimed at changing these circumstances for the sake of mastering things, the unrestrained consumption of them, and power over them. Possession is also the attitude of man to his inner world as a subject matter. In education, this is reproduced as an orientation to "have more knowledge", because the enriched with knowledge is more likely to enrich things. Consumption of knowledge, according to E. Fromm, in fact, turns out to be an empty occupation, since there is no internal activity, which, incidentally, does not necessarily have to be externally expressed (Fromm, 1990, p. 228).

Modus "to be" implies self-change of the person, internal, spiritualpersonal self-growth, and inalienable activity, aimed at being open and involved in the world. In education, this is reproduced as a focus on "knowing more deeply"; based on cognitive interest comprehend holistic world and oneself in this world; know phenomena through giving them a personal meaning. Such a "meaningful teaching", according to K. Rogers, is not focused on the external result, but for the sake of a sense of health and creative harmony of the inner and outer harmony of man with himself, with other people and with the world at large (Rogers \& Freberg, 2002).

Thus, the dialectic of education is expressed not in some complete knowledge of the individual, but in openness to the development and selfcreation. The inherent in the person openness, orientation on someone or something leads to find the meaning of his/her existence. The principle of openness is one of the basic principles of cognition. Well-known Ukrainian philosopher and psychologist V. Romenets states: "The openness of a person lies not in the fact that he/she can be opened as a turtle, but in the fact that he/she opens her/himself, spreading to the entire world accessible to him/her. This world comes into him/her as a certainty. He/she opened it, not from outside, but from inside" (Romenets, 2006, p. 23). Open knowledge is theoretical, empirical, sensual, intuitive, and rational, based on an array of authoritative data.

Philosophers point out that today there is the strict conflict between the utilitarian technocratic view of education on the one hand, and the need for a democratic society to provide opportunities for individual human development on the other; between the recognized need for personal growth in the education system and the widespread need for knowledge transfer; between the demand for learning freedom and the rigid framework of the traditional system.

The challenge of the 21 st century in the educational sphere is the understanding of the synergetic theory and the related to it the key thesis about the open nature of any social system, in particular, the educational one. Therefore, unlike all previous "scientific paintings", in the synergistic 
picture of the world, the starting point is variability, processivity, the formation of a new whole - that is, everything that characterizes the processes of self-organization that take place in nonlinear environments. Self-organization reveals the essence of the process more precisely and more fully, since the reaction to external influences depends not only on the magnitude of this influence, but also on the inherent properties of the system (Kagan, 2007).

Taking into account the synergistic principle of self-organization of open systems expands the possibilities of analysis of education modeling, creates the most optimal conditions for its systematic understanding. Indeed, today, as never before, we need a holistic view of education, with an emphasis on the dynamics and mechanisms of self-organization of the subjects of the educational space, the unity of education and upbringing, the education of a holistic creative personality. At the same time the most important values of modern education are such universal human values as freedom and creativity. Freedom, as an opportunity to act in the absence of external direction, and creativity, as human activity to create new qualities, knowledge, meanings, become the basic axiological dimensions of education.

Thus, in the context of the synergistic paradigm methodology, the center of research and modeling of educational systems shifts towards internal mechanisms of development. In addition, through the lens of synergistic vision it is examined the essence of the individual, who is included in the holistic system of education. In fact, synergetic bestly illuminates the spontaneity of self-unfolding of the inner content of the individual.

It is important to emphasize that, from a synergetic point of view, meaning and context cannot, in principle, be submitted to the student in a ready-made form, given from the outside, but requiring internal selforganization. Therefore, it can be argued that the synergistic foundations of education require the creation of a new, open system of education, where a person reveals himself as a person. Synergetic actualizes the need to develop a new paradigm of education, which allows to move from the process of given to the student a certain minimum of knowledge, mastering the educational standard, to its immersion in the problem of human relations with nature and society.

Therefore, if to consider the phenomenon of education in a broad socio-cultural context, then education for the individual is always and in each case means the possibility to reveal his or her essential forces. This possibility is realized by man, first of all, in search of the sense of being. Thus, another fundamentally important point in the analysis of educational intents is opened. "To be a man, - writes V. Frankl, - means to go beyond 
himself the essence of human existence lies in his self-transcendence" (Frank, 1990; Rogers \& Freberg, 2002, p. 51).

Indeed, in the context of the transition to the information society, when "information becomes more and less meaningful" (J. Baudrillard), the task of education is to create the conditions for the realization of a person's desire for getting a sense, its identification and comprehension. In this case, it is not just about adapting to existing social experience, reproduction of knowledge, but about developing one's own existential position in the process of education (Baudrillard, 2004).

A. Asmolov draws attention to the fact that in general, today there are two basic paradigms in education - "informational, command, and semantic, creative. When we choose one of these paradigm we choose the future, the culture we want to live in - totalitarian or humanistic, the culture of Utility or the culture of Dignity" (Asmolov, 1996, p. 676). In his opinion, education, which is pragmatically focused on the model of the specialist, forms a depleted one-sided personality, the information glut, which is inherent in the scientific and technical age, brings the educational system to a standstill of "substantive self-centeredness". The only way out is to "embark on a different path, the path of a meaningful and creative paradigm in education" (Asmolov, 1996, p. 677). Therefore, to find the sense of life is possible in education, "which creates a meaningful picture of the world and helps make life decisions in uncertain situations" (Asmolov, 1996, p. 678).

\subsection{Analysis of the real practice of higher education}

The relevance of the mentioned above theses is multiplied by the socio-cultural crisis of our society, the disintegration of the usual value system, the changing of stereotypes in a professional career building and professional development. Analyzing the process of higher vocational education, we can formulate the following contradictions:

- between the declared in the pedagogical practice orientation on the student's personality development, and the dominance in the teachers' training of the classical educational paradigm, aimed at subject preparation, assimilation of constantly increasing amount of knowledge and skills;

- between the need to create conditions for the development of the student as a future professional and the dominant focus on him as an object of pedagogical influence;

- between the need for spiritual and value-emotional development of the personality of the future specialist and the lack of psychological and pedagogical conditions and mechanisms that ensure the solution of this problem in the process of studying in higher educational institution (Radchuk, 2014). 
The real practice of higher vocational education indicates a serious deformation of the professional formation of the personality of the future specialist, which leads to deformation of human consciousness - the alienation of him/her from his/her personality, loss of professional sense, prospects of the future, helplessness and devastation. Researchers focus on the disturbing tendency in the development of the humanitarian aspect of educational content, which is reflected in its verbalization and rationalization. Information overload blocks the affective-emotional sphere of the individual, prevents adequate, holistic perception of reality, entering into emotional contact with him, his meaningful comprehension and "living". The emotional world of the individual, his creative potentiality, productive thinking is actually superseded by the dominance of information.

Here, the problem of higher vocational education of the humanitarian professionals is extremely acute as there are serious requirements for moral qualities of them and their values development. Higher pedagogical education, says M. Kagan, focuses primarily on the "training of "subject teacher", has more or less effective teaching methods to teach the basics of subject, but not so cold "teacher-creator", which is designed to shape the Person as a whole and unique Individual who responds to the demands of a new historical type of culture of the $21 \mathrm{st}$ century" (Kagan, 2007). Analyzing the process of future psychologists training, G. Breslav raises the logical question of how one can be attached "to the values of "non-directional psychology" in a rather rigid training model, which nevertheless is closer to the ideology of "preparation" rather than "education" (Breslav, 1997, p. 252).

So, there is a need to overcome one-sided technocratic tendencies in the professional training of the future specialist, which are manifested in insufficient consideration of his personal formation and direct efforts to develop specific humanitarian educational technologies (Radchuk, 2017).

\section{Conclusions and prospects for further research}

Thus, on the basis of theoretical and methodological analysis, four basic educational paradigms have been identified: cognitive-informational (traditional, cognitive), personal (humanistic), competent and cultural (humanitarian). It is found that, unlike instrument-oriented learning, which provides the translation, reproduction and assimilation of knowledge, skills, technologies (cognitive-information and competence paradigms) and therefore is secondary to the processes of personality development, education should first and foremost be focused on becoming holistic personality, ensure its organic and unique (personal and cultural paradigms). 
It can be stated that at the theoretical level there is a sharp narrowing of the semantic field of scientific and pedagogical reflection: attention is paid to the production of the sum of knowledge, given social behavior, technologies of the future specialist activity. Insufficient understanding of the essential aspects of the educational process leads to an orientation to formal, technological aspects, to over-enthusiasm in calculating points, credits, and nourishes the very meaningful content of education.

In such conditions, the education in its humanitarian sense suffers first of all, and the quality of education is often reduced to the level of mastering professional knowledge and skills. Higher education institutions are increasingly inclined to pragmatic training of professional functionaries. But, the main goals of modern higher education should be the cultural orientations which allow substituting knowledge approach to meaningful, where both the teacher and the student are active participants of educational activity.

Thus, the reform of education should be based on the idea of the integrity of education, which actualizes the problem of careful reflexive and methodological support of the modern higher education system and the development of specific humanitarian educational technologies.

\section{References}

Asmolov, A. G. (1996). Kulturno-ystorycheskaia psykholohyia y konstruyrovanye myrov (Cultural-historical psychology and world-building). Institute of Practical Psychology, Voronezh: MODEK. 768 p.

Baudrillard, J. (2004). Symvolichnyi obmin i smert (Symbolic exchange and death). Calvary. $376 \mathrm{p}$.

Bondarevskaya, E. V., Ivanova, E. O., \& Osmolovskaya, I. M. (2005). Teoryia y praktyka lychnostno-oryentyrovannoho obrazovanyia. Lychnostno-oryentyrovannoe obuchenye: Khrestomatyia [Theory and practice of personality-oriented education. Personalized Oriented Learning: Readers]. SSU. pp. 116-162.

Breslav, G. M. (1997). Obrazovanye y podhotovka psykholohov: dylemmy humanystycheskoi psykholohyy[ Education and training of psychologists: dilemmas of humanistic psychology]. In D. A. Leonteva, \& V. G. Shchur (Eds.), Psykholobyia s chelovecheskym lytsom: bumanystycheskaia perspektyva v postsovetskoi psykholohyy (Psychology with the Human Face: A Humanist Perspective in Post-Soviet Psychology). Sense. pp. 249-256.

Frank, V. (1990). Chelovek, vpoyskakh smusla (Man in Search of Meaning). Progress. 367 p. Fromm, E. (1990). Ymetyly but (Have or be). Progress. 336 p. 
Gusinsky, E. N., \& Turchaninova, Y. I. (2000). Vvedenye v fylosofyiu obrazovanyia: Ucheb. posobye [Introduction to the Philosophy of Education: Textbook]. Logos. 223 p.

Kagan, M. S. (2007). Systemno-synerhetycheskyi podkhod k postroenyiu sovremennoi pedahohycheskoi teoryy. Synerhetycheskaia paradyhma. Synerhetyka obrazovanyia [System-synergetic approach to the construction of modern pedagogical theory. Synergistic paradigm. Synergetics of education]. Progress-Tradition. pp. 212-245.

Radchuk, G. K. (2014). Aksiopsykholohiia yyshchoi shkoly (Monohrafiia) [Axiopsychology of high school (Monograph)]. Ternopil, TNGU named after V.Gnatyuk. 380 p.

Radchuk, G. K. (2017). Osvitnii dialoh yak innovatsiina humanitarna tekhnolohiia profesiinoho stanovlennia osobystosti. Pedahohichnyi protses: teoriia i praktyka / Zbirnyk naukovykh prats [Educational dialogue as an innovative humanitarian technology for the professional development of personality. The pedagogical process: theory and practice / Collection of scientific works]. Kyiv, LLC EDELVEYS Publishing Company, 1, pp. 3 19.

Rogers, K., \& Freberg, J. (2002). Svoboda uchytsia (Freedom to learn). In A. B. Orlov (Ed.). Nauch. The Meaning. 527 p.

Romenets, V. A. (2006). Vchynok i postannia kanonichnoi psykholohii [The act and figure of canonical psychology]. In V. O. Tatenka (Ed.), Liudyna. Subiekt. V chynok: Filosofsko-psykholohichni studii [Man. Subject. Action: Philosophical and Psychological Studies]. Lybid, p.11-36. 